\title{
History of partnership between agro-industries and oil palm smallholders in Cameroon
}

\author{
Raymond N. Nkongho ${ }^{1, \star}$, Thomas E. Ndjogui ${ }^{1}$ and Patrice Levang ${ }^{1,2}$ \\ ${ }^{1}$ Center for International Forestry Research (CIFOR), PO Box 2008, Yaoundé, Cameroun \\ 2 Institut de Recherche pour le Développement (IRD), GRED, Montpellier, France
}

Received 20 October 2014 - Accepted 20 January 2015

\begin{abstract}
The present article explores the origin and changes in partnership agreements established between agroindustries and oil palm smallholders in Cameroon. The different forms of partnership which have existed over the years in the oil palm sector until now are assessed, notably the FONADER-sponsored smallholder scheme (1978 to 1991) and more recently the Afriland First Bank sponsored villagisation project of Socapalm Eseka (2007/2008 to present). Special attention is given to the factors and conditions that have influenced the outcomes of these partnerships, specifically the failure of the FONADER-sponsored smallholder scheme. The authors conclude that with the current absence of steady support from the government to oil palm smallholders, especially after the implementation of the structural adjustment plans, private partnership schemes between agro-industries and oil palm smallholders could be highly profitable for both stakeholders. Such partnerships can foster social cohesion and limit further encroachment of agro-industries into the primary forest, provided such partnership agreements are carefully planned and adequately implemented.
\end{abstract}

Keywords: FONADER / Afriland First Bank / partnership / smallholders / agro-industry / oil palm

Résumé - Histoire du partenariat entre les agro-industries et les petits exploitants de palmiers à huile au Cameroun. Cet article étudie l'origine et l'évolution des accords de partenariat établis entre les agro-industries et les petits exploitants de palmiers à huile au Cameroun. Les différentes formes de partenariat qui ont existé dans le secteur de l'huile de palme au fil des ans jusqu'à présent sont évalués, notamment le projet FONADER qui a parrainé les petits exploitants (1978 à 1991) et, plus récemment, Afriland First Bank qui a parrainé le projet villagisation de Socapalm Eseka (2007-2008 jusqu'à présent). Une attention particulière est accordée aux facteurs et conditions qui ont influencé les résultats de ces partenariats, en particulier à l'échec du parrainage des petits exploitants par le FONADER. En l'absence actuelle de tout soutien significatif de la part du gouvernement aux petits exploitants de palmiers à huile, en particulier après la mise en oeuvre des plans d'ajustement structurel, les programmes de partenariat privé entre les agro-industries et les petits exploitants de palmiers à huile pourraient être très bénéfiques aux deux parties prenantes. Ces partenariats peuvent favoriser la cohésion sociale et limiter l'empiétement des agro-industries sur la forêt primaire, à condition que ces accords de partenariat soient soigneusement planifiés et bien mis en oeuvre.

Mots clés : FONADER / Afriland First Bank / partenariat / petits exploitants / agro-industrie / palmier à huile

\section{Introduction}

The oil palm (Elais guineensis) is a perennial plant native to the humid tropics of West and Central Africa which grows between 10 degrees North and 10 degrees South latitude. In these regions it is very common to find oil palm growing spontaneously in the wild, in isolated stands or as natural oil palm groves.

The human populations living in the forest zone of Cameroon have always been using oil palm products: the crude red oil extracted from the mesocarp of the fruit, the oil con-

\footnotetext{
^ Correspondence: nrndip@yahoo.com
}

tained in the kernel (sometimes called white oil) and the sap which ferments spontaneously to generate palm wine. However, palm oil (its main product) led to its worldwide success as far back as the first half of the 19th century. This was the result of an increased demand generated by the industrial revolution in Europe (notably to lubricate railway truck axles) and, to a lesser degree, for palm kernel oil as the margarine industry developed in Germany and the Netherlands (Jannot et al., 2003).

The development of the oil palm sector in Cameroon began with the harvesting of spontaneous oil palm groves and the incorporation of sprouted seedlings into farmlands inside 
agroforestry systems. The annexation of Cameroon by the Germans induced the development of large scale plantations by private German firms before WWI. After the defeat of the Germans by the British and the French in 1916, the industrialization of these plantations began with the creation of Pamol plantations in 1928 then the Cameroon Development Corporation (CDC) in 1947/48, before Independence and reunification, respectively in 1960 and 1961. During this period, very little was done to develop the smallholders' oil palm sector. Although Pamol began with the development of village plantations for the local population in the 1960s and 1970s, CDC on its part did very little to develop oil palm plantations for the local population. After the creation of "la Société camerounaise de palmeraies" (SOCAPALM) in 1968 under a Nucleus Estate Smallholder (NES) model, it is only in the late 1970s that the government of Cameroon - as part of its poverty reduction strategy - decided to develop oil palm smallholdings for the locals. A partnership between major agro-industries and oil palm smallholders was created with funding assistance from the World Bank and it was placed under the supervision of the "fonds national du développement rural" (FONADER) (Ndjogui et al., 2014, Nkongho et al., 2014). According to Carrère (2010), about 35000 ha of smallholdings were developed within 12 years during the FONADER-sponsored scheme.

Our research followed three main objectives: (i) to trace changes in the oil palm industry in the country; (ii) to describe its various stakeholders and (iii) to analyze the different partnership schemes that were put in place by institutions over time in order to develop the oil palm sector in Cameroon and some of the challenges they faced.

\section{Methodology}

The present research work relies on multiple sources of information. A thorough literature review has been conducted through data mining from scientific publications, students' thesis and reports from various public services, NGOs and international institutions. Media reports were also analyzed on the internet. Oil palm companies also contributed to our sources by the kind opening of their archives and statistical information even if very little historical data was available from the archives of the companies.

Our literature review was complemented by three field surveys conducted in 2011, 2012 and 2013 in the Centre, Littoral and Southwest regions in which major oil palm development took place over the years. These regions harbor five agroindustrial oil palm companies (Socapalm, Pamol, Cameroon Development Corporation (CDC), Société des Palmeraies de la Ferme Suisse (SPFS), and Safacam) and more than three quarters of all oil palm smallholders/holdings are located in these regions. Figure 1 shows the location of large oil palm companies in the Cameroon oil palm belt.

Our research focused on the various ways oil palm was cultivated locally before the development of monocultural oil palm plantations by agro-industries. It was aimed at analyzing the various partnership models which existed or are still existing between plantation companies and smallholders, the reasons for the collapse of these partnerships when it oc- curred and the emergence of the second generation of oil palm "smallholders".

Lastly our survey intended to understand the current measures put in place by agroindustries to strengthen their bonds with oil palm smallholders and to study innovative strategies from the government of Camerooon for the development of the oil palm sector. A total of 155 respondents were interviewed through a purposive sampling method in the course of a survey which consisted in 3 field trips of about 3 weeks each. The distribution of the sample was as follows: 35 retired company officials (senior supervisors and managers), 35 company officials in active service (senior supervisors and managers) and 80 key palm oil producers (50 from the FONADER scheme and 30 from the so called "Projet Villagisation") including 5 officials from the Ministry of Agriculture and Rural Development. In case of doubt, the same questions were crosschecked with other resource persons in order to ensure their validity.

\section{Results}

This section is divided into the following sub-headings; a historical overview of the oil palm sector in Cameroon, Pamol Plantations and the development of oil palm smallholders, Cameroon Development Corporation (CDC) and relations with oil palm smallholders, the nucleus estate and smallholder (NES) partnership (FONADER sponsored scheme), the collapse of FONADER and the emergence of independent palm oil producers, Projet Villagisation in Socapalm Eseka, as well as current measures adopted by agro-industries to strengthen links with smallholders.

\subsection{A historical overview of the oil palm sector in Cameroon}

Before the arrival of the European colonizers, the local population inhabiting the forest zone of Cameroon harvested the native variety of oil palm (dura) from spontaneous groves for subsistence and trade. Oil palms were harvested in the wild and introduced on farmland through the collection of sprouted seedlings from oil palm groves and they were grown in association with other food and cash crops. It is only with the arrival of the German colonizers by the end of the 19th century that large scale cultivation of oil palm started. As far back as 1877 , Douala Chiefs requested Britain to establish a protectorate. The British procrastinated for seven years and by the time they finally made their move, it was too late. The native chiefs, tired of waiting for the British to make up their mind, contracted a treaty with Gustav Nachtigal, representing Germany, on July 14, 1884 (Bederman, 1968). Almost a year later, in 1885, the British recognized all German claims, except those involving Victoria. After negotiation for compensation for the Baptist Missions, the British abandoned all claims to Kamerun in 1886 , and shortly thereafter, the Basel Mission took over the work of the Baptist. France recognized the German Protectorate in a treaty signed on December 1885.

The Germans were faced with two major problems in the course of their trade with the indigenous population of 


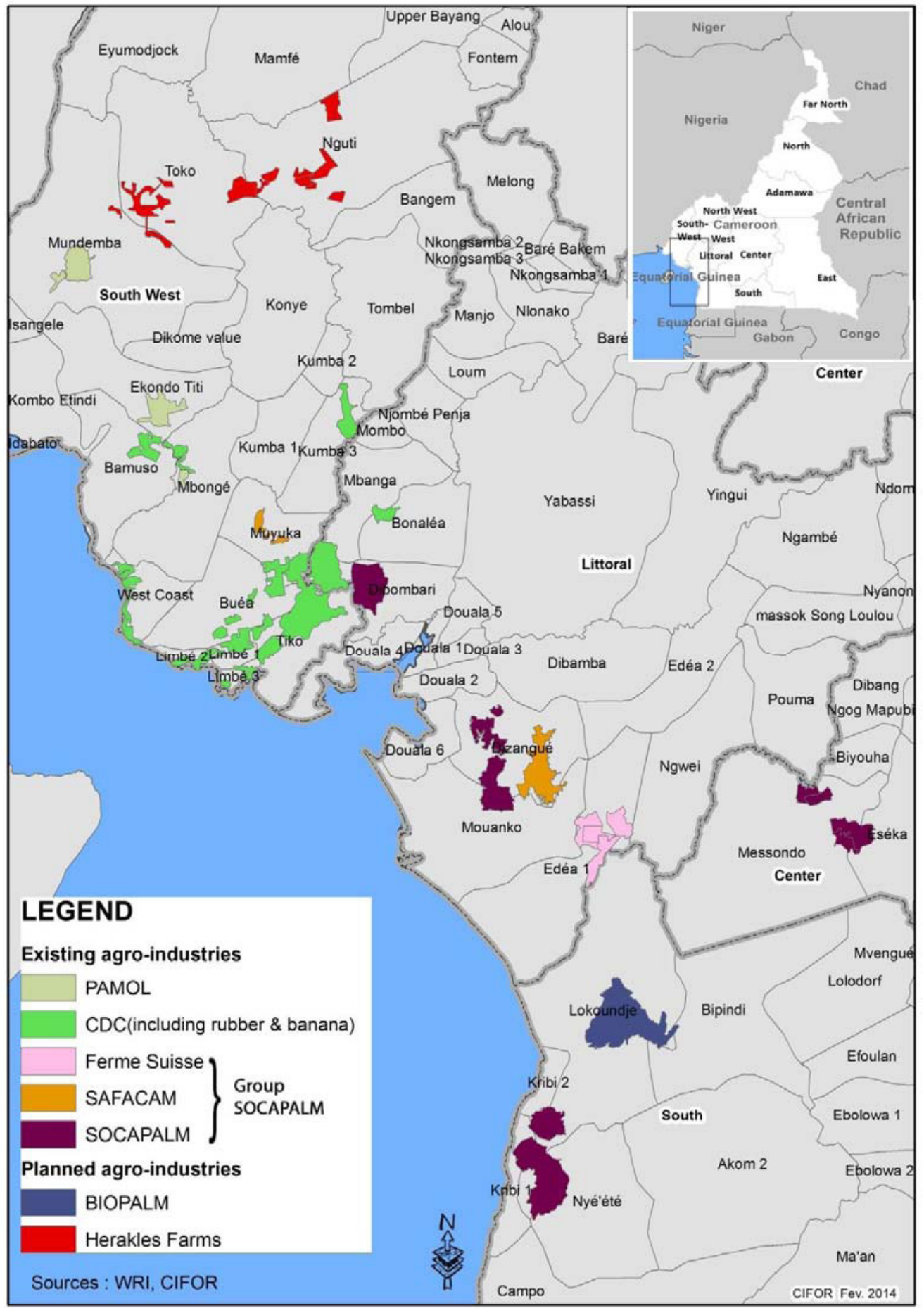

Fig. 1. Map of agro-industrial oil palm companies in Cameroon.

Kamerun. First, the coastal chiefs in Douala refused to allow the Germans to trade directly with the populations in the hinterland since they were making a lot of profit from their position as middlemen between the indigenous traders and the Germans. Second, the major waterways on either side of the territory were controlled by the British and the French. The Germans then sent explorers around Mount Kamerun to nego- tiate with local chiefs in order to improve trade. It quickly became apparent to the Germans that the lower slopes were quite suitable for commercial exploitation. In the Mount Kamerun area alone, the Germans alienated 400 square miles of the most fertile land ( 83000 hectares belonging to the indigenous Bakweri). In fact, they seized the land without financial compensation to any of the rightful owners. According to Courade 
(1984) the Bakweri were forced either to move into prescribed restricted native reserves or outside the alienated lands.

Even if much land was alienated from the Bakweri it was not totally exploited by the private German plantations. Throughout the German colonial period the most important plantation crops were cocoa, rubber and oil palm. Minor crops were kola, tobacco and coffee and almost all were exported to Germany. In 1892 the Germans established a botanical garden in Victoria (presently called Limbe). The purpose of this garden was to undertake experiments on different types of soils at different elevations and under variable moisture conditions. The botanical garden distributed free seeds and cuttings to the local population and at the same time it provided valuable information about the proper exploitation of the colony's resources.

Before the interwar period (1916 to 1939), the first industrial plantation in Kamerun was initiated in 1907 under the German colonial rule, leading to the creation of the Edea oil palm estate in 1909, which was later renamed "Société des palmeraies de la ferme suisse (SPFS)". The Germans continued the development of industrial plantations on the fertile slopes and plains of Mount Fako until the beginning of World War I. Shortly after WWI began, the British and French forces invaded the German colony. By December 1914, the British were controlling the Victoria division. By February 1916, the whole Kamerun territory was in the hands of the British and French. One month later an agreement dividing Kamerun between the two countries was signed in London. In July 1922, the smaller British portion became a mandate of the League of Nations and was assigned to the United Kingdom to be administered along with Nigeria. The properties of the German citizens were confiscated and turned over to the "Custodian of Enemy Property" to be administered for the duration of the war. In 1924, properties in both the French and British sectors were put up for sale. In French Cameroon, the former German plantations were purchased by French, British and Cameroonian businessmen. This was the direct opposite of what happened in the British Cameroon as almost all the plantations were purchased by their former German owners. In addition to land, the sales included the railway system, rolling stock, bridges, wharves and all dwellings and factories. Between 1925 and 1939, most of the trade between British Cameroon and Europe occurred through Germany. At the outbreak of World War II in 1939, the German properties were expropriated again by the 'Custodian of Enemy Property' and with this act, the German activity in Cameroon came to an end.

By 1919, in the western part of the country occupied by the British, four of these plantations were bought by the Unilever group (they include Bwinga, Bai, Lobe and Ndian) which in addition obtained a concession area of 10,000 ha for the creation of "Pamol Plantations" (Barbier et al., 1980). In 1947, the Cameroon Development Corporation (CDC) was created from the merging of former German plantations around Mount Fako. Meanwhile another former German plantation "La Plantation de Dizangué" was bought in 1959 by the Rivaud group. This plantation is known today as the "Société africaine forestière et agricole du Cameroun (SAFACAM)". The last agro-industry to be developed "la Société camerounaise de palmeraies (SOCAPALM)" was created in 1968 by the Government of Cameroon, then privatized in 2000. SOCAPALM, SAFACAM and SPFS are now controlled by the French group Bolloré, while CDC and Pamol are the only remaining public companies (Carrère, 2010; Oben and Fanso, 2012; Ndjogui et al., 2014).

\subsection{Pamol plantations and the development of oil palm smallholdings}

Pamol plantations actually began with the development of smallholder plantations in the 1960s/70s. Six villages with customary rights to the land leased to Pamol Plantation in Lobe actually benefitted from the creation of 10 hectares of demonstration farms in each of these villages. These were namely: Ngolo-Metoko, Bogongo 1, Lipenja, Kumbe Balondo, Lobe town and Ekondo-Titi. The farms were entrusted to the villagers through the village council that was headed by a chief. While the villagers were in charge of inter-row slashing the company undertook the harvesting and pruning of the palms. Four reasons prompted Pamol Plantations to open oil palm plantations for the benefit of these villages: (i) corporate social responsibility; (ii) the need for an extra supply of fresh fruit bunches; (iii) to divert the villagers from stealing fruits from the company's plantations and last but not least, (iv) the company realized that it was cost-effective to open smallholder plantations instead of embarking on new development of its own plantations due to huge costs. This was verified when the company wanted to carry out an extension of the NgoloMetoko division (Nkwain, Field Assistant Pamol, pers. com.).

Pamol encouraged smallholders to open plantations on their own with the hope that they would supply their palm fruits to the company. Incentives included the supply of selected planting material either at subsidized rates or free of charge. The company went further in the 1980s and early $1990 \mathrm{~s}$ and it recommended to the farmers to group into cooperatives in order to facilitate the running of its Smallholders Department. As a result a number of cooperatives sprouted which included: Campers, Mushcoops, Secoops, Ekoscoop, Manja Youths CIG, Mebeek CIG, Providence CIG, Catholic Mission Ikassa and others. The advantages of membership included the possibility of buying seeds at discount rates from the company at $100 \mathrm{FCFA}(0.15 €)$ instead of $200 \mathrm{FCFA}(0.3 €)$, an access to credit from the bank and a better position for negotiation with Pamol management on issues of common interest for the farmers. But these cooperatives did not last for long due to corruption practices, power tussle amongst its members and embezzlement of funds (Metuge, retired Divisional Manager Pamol, pers.com.).

\subsection{The Cameroon development corporation (CDC) and its relationship with smallholders}

After independence and re-unification of Cameroon, the CDC invited experts from the Commonwealth Development Corporation headed by Swynnerton in 1964 to draft a long term development plan for the company. In its report, the mission advised the company to set up various smallholder schemes for rubber, oil palm and tea and to extend its role 
in smallholder development from trade to production. Such a role included the continuous supply of inputs, credit and technical advice as well as a strict supervision process. It was also recommended to install a Smallholder Development Authority by the Federal State of West Cameroon, which would be responsible for the planning and implementation of smallholder schemes in the territory. This recommendation unfortunately never came into fruition.

Though the Swynnerton proposal was not implemented neither by CDC nor by the federal government, CDC became involved in smallholder development (Konings, 1993). After independence and re-unification (which was concomitant with a sharp decrease in banana production at CDC, due to a fall in price at the world market) most banana farmers were grouped into cooperatives, notably the Bakweri Cooperative Union of Farmers (BCUF).

These farmers decided to use their saved capital to diversify into oil palm and rubber production. Farmers then resorted to $\mathrm{CDC}$ to support the purchase, transportation and marketing of their palm fruits. The West Cameroon Department of Agriculture and Cooperative was very instrumental in the negotiating process between farmers and CDC. This farmer's group was made of various peasant and middle-class farmers with discrepancies in terms of plantation area. Their major problem after reaching a consensus with CDC was that most of their plantations were scattered all over the Southwest Region thus making the management by CDC very difficult. More, they had to struggle with low purchasing prices for their palm fruits from CDC (Konings, 1993).

\subsection{The nucleus estate and smallholder (NES) partnership (FONADER sponsored scheme)}

The 1960s were the time of decolonization in Africa. Most African countries then opted for the diversification of their agricultural income and for the local processing of agricultural products. Countries from the "oil palm belt" promoted the development of oil palm amongst other crops such as cocoa, coffee or rubber (Bakoumé, 2006; Jannot, 2010). The Government of Cameroon was not an exception and followed this trend after the Independence of French Cameroon in 1960 and further unification with British Cameroon in 1961. The new independent government decided to adopt the "Nucleus Estate and Smallholders" (NES) model for its national oil palm development plan. This involved a palm oil mill surrounded by an estate, surrounded itself by plantations owned by smallholders. In 1963, the Government decided to develop the cultivation of oil palm and it created the Socapalm plantation by Presidential decree No. 68/DF/45 on 23 November 1968 (Andela, 2006).

The first oil palm development plan was initiated by the Government of Cameroon with financial support from the World Bank in 1977 and 1978. Under this scheme the first generation of oil palm smallholders came into existence (1977/1978-1990/1991). The plan was developed under the authority of the FONADER. Three agro-industrial oil palm companies benefited from this scheme, namely: CDC, Socapalm and Pamol which were selected for their technical expertise (Courade, 1984; Lebailly and Tentchou, 2009; Rafflegeau et al., 2010; Feintrenie and Rafflegeau, 2012; Feintrenie, 2013;
Table 1. Yearly installment of credit plus interest.

\begin{tabular}{cc}
\hline Year & $\begin{array}{c}\text { Installment } \\
\text { of credit plus } \\
\text { interest (in \%) }\end{array}$ \\
\hline 6 & $5.5 \%$ \\
7 & $10.0 \%$ \\
8 & $14.0 \%$ \\
9 & $16.0 \%$ \\
10 & $17.0 \%$ \\
11 & $18.0 \%$ \\
12 & $19.5 \%$ \\
\hline
\end{tabular}

Source: FONADER contracts.

Ndjogui et al., 2014). Smallholders who wanted to join the scheme were requested to sign a contract with one of the aforementioned companies. Such contracts stipulated the conditions for participation and the mutual obligations of the contracting parties. The most important conditions for participation were the following:

- candidates had to be of Cameroonian nationality and to generate at least $75 \%$ of their income from farming;

- they had to be between 25 and 40 years of age and physically fit to run a farm.

However, older persons who could rely on the labour force from younger relatives could also qualify. Any candidate had to own his proper piece of land which had to comply with the conditions of the contract. Indeed, it had to be: (i) within a radius of $30 \mathrm{~km}$ from the company's mill; (ii) located at less than $500 \mathrm{~m}$ from a road or a track usable by the company's vehicles and (iii) suitable for oil palm cultivation and covered by a land use permit for at least twenty-four years. Finally, candidates had to obtain the company's approval for participating in the scheme (Konings, 1993).

The obligations of the two contracting parties were as follows: farmers had to scrupulously follow all instructions given by the company regarding labour, to attend all meetings convened by the company for training and farm management practice, to sell all their fruit harvest to the company and to settle all their debts with the company. The company had to provide the participating farmers with the necessary inputs, technical advice and supervision. These services were to be rendered on credit and had to be repaid in increasing installments after palms had begun bearing fruits with an annual interest rate of $9 \%$, plus a $2 \%$ deduction from the amounts of these purchases for management fees. The credit to be paid by the farmers included the cost of oil palm development and maintenance for 5 years. The repayment of the credit plus interest was supposed to begin from the 6th to the 12th year, giving a period of 7 years in increasing installment as shown on Table 1. Deduction of credit was based on the age of palms, since FFB production increases with age for about 15 years or more (FONADER contract, unpublished).

Repayment was to be deducted from the sales to the company. In addition, the company's management had to transport the harvested fruits to the mill for a fixed price. Lastly, the company had to pay for the producer's harvest on a monthly basis. Participants were expected to run between 2 and 5 ha 
of plantations with improved planting material. The consequence of any failure to comply with the terms of contract was the immediate seizure of the land by the company. The contract covered a period of 27 years from the year of first land clearing, and following the repayment of all debts, the participants were to receive a land certificate registered in the survey department. During the early period of immature plantation, the farmers were granted a non-refundable cash grant of 56900 FCFA (86.74 €) lumpsum as a remuneration for their labour input. The project went further to foster rural development through continuous roads and infrastructures maintenance in areas where these smallholders oil palm plantations were located and this was part of the companies' obligations to the Government (Konings, 1986; Bakoumé et al., 2002; Rafflegeau, 2008).

Before the collapse of FONADER in 1990 a Smallholders Department was operating as a separate entity in each of the agro-industrial companies, under a separate management from the nucleus estate. Each Smallholders Department was in control of its own personnel, material and transport facilities. This greatly facilitated relationship with farmers as the transportation of fresh fruit bunches from the farms to the nucleus mill was done on time. Coupled with material and technical support given to the farmers, this greatly kept the relationship between the two parties alive.

\subsubsection{The collapse of FONADER and the emergence of independent palm oil producers}

Both internal and external factors have caused the collapse of FONADER. Internally the FONADER management was over-centralized with the absence of acting representatives at the regional and divisional levels around the country. This was a major cause of delay in disbursing funds earmarked for on-going projects. Other studies suggested that the government might have diverted funds from FONADER to other non-productive sectors. In the oil palm sector, it was found that some companies paid more attention to their own plantations than to smallholders' ones. Foko (1994) reports that a huge amount of paperwork was necessary before benefiting from FONADER funds and this was probably another limitation for the rural population which was still partly illiterate. Elong (2003) stresses that about $70 \%$ of the total smallholder plantations developed in lower Mungo by 1989 fell in the hands of urban elites. The external causes which led to the collapse of FONADER include: (i) the withdrawal of the World Bank which was considered as a major source of funding for FONADER; (ii) the decline in global export prices of several agricultural commodities such as coffee, cocoa, cotton or banana; and (iii) the withdrawal of the Government from the productive and most especially the rural sector due the economic crisis of the late 1980s.

After the bankruptcy of FONADER in 1990, a new generation of oil palm smallholders came into the game. This was due to a series of concomitant factors which included: the reduction of a large number of civil servants in the Cameroon public service due to the structural adjustment program, the economic crisis, the devaluation of the CFA Franc, a fall in the international market for cocoa and coffee (two important cash crops on which most farmers relied for their income) and an increase in the domestic price for palm oil (Ndigui et al., 2006; Nkongho et al., 2014). The structural adjustment program imposed by the International Monetary Fund on the government of Cameroon in the late 1980s accelerated the privatization of 15 public enterprises in the transportation and agro-industrial sector in July 1994 (Hirsch, 1995; Konings, 1996, 1997; Cheyns and Rafflegeau, 2005). This led to the liberalization of the palm oil sector. As a consequence, the number of artisanal palm oil mills scattered all over the oil palm production basins of Cameroon increased sharply (Hirsch, 2000; Nkongho et al., 2014). This second generation of oil palm smallholders was not only made of peasant farmers but also of internal or external elites. Internal elites include former workers with the public and private sectors on retirement and who wanted to live as pensioners in their village of origin together with village leaders. External elites include the same category of people, but who do not reside in the village. Some of these elites hold top positions in the public and private sectors. Most of them single-handedly sponsored their oil palm plantations, with very little or no support from the government and some of them opened large estates of 50 ha and above as shown in Figure 2. This figure describes the areas of oil palm plantations owned by elite palm oil producers in four production basins in the forest zone of Cameroon when investigated in 2011. When compared to their first generation counterpart under the FONADER scheme, second generation oil palm planters owned larger land areas.

After the collapse of FONADER the companies had to merge the management of the Smallholder Department with that of the Nucleus Estate in order to reduce running costs. Some of the top executives saw this merging as a unique opportunity to divert resources that were previously dedicated to smallholders for their personal use. Such dishonest behaviours were made possible by very poor tracking records in the companies. Priority was also given to the milling of fruits from the Estate and to the payment of salaries of the company's workers. Smallholders also complained about the purchase price for fresh fruit bunches which - at 25 to 40 FCFA (0.04 to $0.06 €)$ per $\mathrm{kg}$ - was not covering their production costs. The closure of Smallholder Departments as independent entities made most smallholders reluctant to supply their fruits to the company mill in order to pay back their loans. There were recurrent conflicts and intimidations between company officials and oil palm smallholders who did not comply with the payment of their loans (Njanjo, retired Senior Smallholder Overseer CDC, pers. com.). According to Foko (1994), local populations considered credit support through government banks like FONADER as a gift, and this made them very reluctant to reimburse their loans.

Facing such challenges, most of the new generation of oil palm smallholders started searching for independent ways of processing their fresh fruit bunches and this led to an upsurge in the number of artisanal mills both within the periphery of the agro-industries and in far-off areas (Rafflegeau et al., 2010; Nkongho et al., 2014).

During the same period the occurrence of fruit theft increased in the major oil palm agroindustries, a situation that is still rampant today (PACA, 2009; Nkongho et al., 2014). 


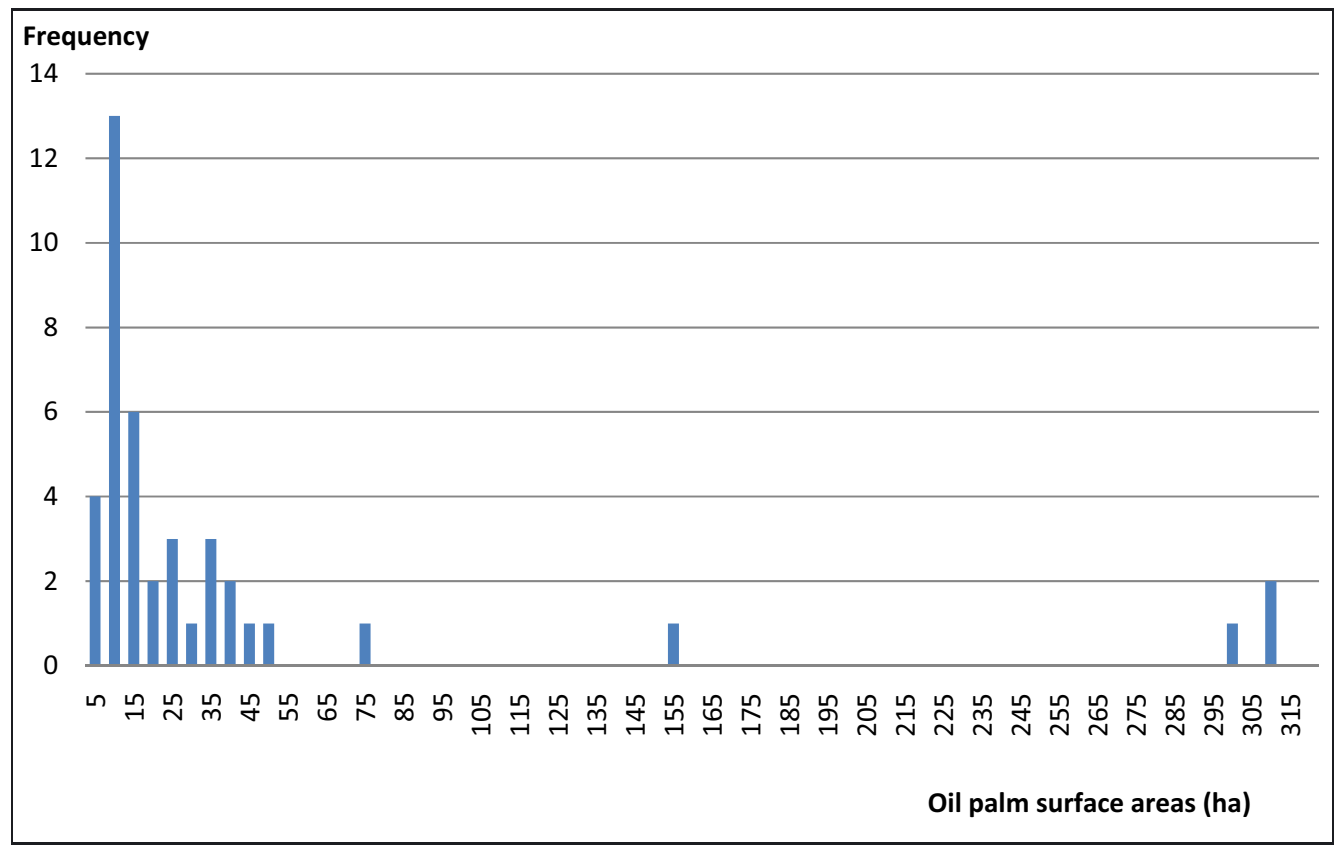

Fig. 2. Distribution of surface areas for elite planters.

Table 2. Cultivated areas and productivity in agro-industries and smallholders in Cameroon.

\begin{tabular}{cccccc}
\hline Year 2012 & $\begin{array}{c}\text { Surface } \\
\text { area } \\
\text { (ha) }\end{array}$ & $\begin{array}{c}\text { Mature } \\
\text { area } \\
\text { (ha) }\end{array}$ & $\begin{array}{c}\text { Immature } \\
\text { area } \\
\text { (ha) }\end{array}$ & $\begin{array}{c}\text { Production } \\
\text { tons } \\
\text { CPO }\end{array}$ & $\begin{array}{c}\text { Yield } \\
\text { tons } \\
\text { CPO/ha }\end{array}$ \\
\hline CDC & 14352 & 10250 & 4102 & 18309 & 1.79 \\
Pamol & 9526 & 9133 & 393 & 12878 & 1.41 \\
Safacam & 4792 & 3936 & 856 & 11742 & 2.5 \\
Ferme Suisse (SPFS) & 3683 & - & - & 11000 & 2.99 \\
Socapalm & 32000 & - & - & 86000 & 2.69 \\
Smallholder plantations & $40000-100000$ & - & - & 90000 & $2.25-0.9$ \\
Total & $100670-160670$ & & & 229929 & \\
\hline
\end{tabular}

Source: Field survey, data from agro-industries, 2013.

It is important to note that the present relationship between oil palm smallholders of both generations and major agroindustrial companies is a matter of convenience. This implies that most smallholders can only supply their fresh bunches to the nucleus mill either during peak production period when they are aware that the capacity of their artisanal mills or commercial artisanal mills cannot accommodate the supply of fresh bunches from their plantations or when their artisanal mills gets out of order. It is rare to find any smallholder today who delivers $100 \%$ of his fresh bunches to any of these companies.

At present, oil palm growers are faced with four major problems which include: very little access to credit, availability of certified selected seeds, inputs, and technical capacity building (Ndoum, 2009; Ngom, 2011; Feintrenie, 2012; Nkongho et al., 2014). This situation has serious effects on the production capacity of smallholders, as shown on Table 2. Moreover, public companies like Pamol and CDC also struggle with very low yields when compared to private companies. A company like Pamol has not ammended its plantations with fertilizers for the past 28 years.

\subsection{Projet villagisation in Socapalm Eseka}

Socapalm was developed in 1968 as a way of stepping up the production of palm oil and to generate income and employment opportunities for the local population. By 1978, the government also initiated a smallholders scheme and Socapalm was selected for the development of village plantations. The project was well accepted in the surrounding villages. With the collapsing of the scheme in the early nineties due to the FONADER bankruptcy, the smallholders were left alone. Socapalm was a publicly owned company from its creation until 2000 when the Government decided to privatize the company. Immediately after Socapalm was privatized, it faced stiff resistance from the local population who either wanted their land back or asked for massive compensations from the company's owners. Local populations found that when their land was seized by the Government in the late 1960s for the development of Socapalm, no reasonable compensation was given to the villages who had customary rights to the land. The case of Socapalm Eseka was not an exception and this prompted the company to start looking for ways of working together with 
the local population. As a result, the Villagisation Project was designed to begin at Eseka at first and then to spread to the other Socapalm estates in Dibombari, Mbongo, Mbambou and Kienke.

The Villagisation Project at Socapalm Eseka started in 2007. Upon the privatization of Socapalm, 6485 ha was the total concession area of Socapalm Eseka. Within this area, 2601 ha were made up of very old palms planted between 1970 and 1973. Such palms should have been replanted because they were already older than their normal economic life span and the remaining area of the concession was supposed to undergo extension.

Socapalm faced stiff resistance from the local population of Eseka to carry out the replanting of the 2601 ha piece of land made up of old palms. According to the local population, it is the palms that were privatized by the Government to the company but not the land. Thus they did not see any reason why the company had to embark on a replanting scheme. In short, the native people never liked the idea of privatization and considered that the government should have given the land back to them.

There was also a high level of theft by the local population who frequently encroached into the plantation to steal fresh fruit bunches. This situation - coupled with the old age of palms - made the cost of production very high for the company thus it was difficult for Socapalm to break even. This led to a series of layoffs of some company workers at Socapalm Eseka and management at the general directorate thought it was time to come into a consensus with the local population by starting the Villagisation Project.

\subsubsection{Stakeholders of the project}

The project is $95 \%$ funded by Afriland First Bank for a 1423000000 FCFA (2 $169353 €$ ) total budget. Each individual who was eligible to benefit from a plot was supposed to pay $5 \%$ of the requested amount depending on the plot area and this amount was paid directly in the account of Socapalm. Socapalm and the German Development Bank respectively paid a $20 \%$ and $80 \%$ deposit on a separate account dedicated to Afriland First Bank in case the planters were unable to complete the re-imbursement of their credit within 8 years. The planters were requested to pay back their credit through the supply to Socapalm of fresh fruit bunches harvested from their plots. As a result, a different agreement was signed between three different consortia, namely (Afriland First Bank, Mitfund, Grower) then (Socapalm, Mitfund, Grower) then (Socapalm, Grower). The contract signed by each of the different stakeholders consortium clearly described the responsibilities of each institution involved in the scheme. Indeed, Afriland First Bank was responsible for the financing of $95 \%$ of the cost of the plots leased by Socapalm to the local population for a period of 25 years.

Socapalm was requested to provide technical expertise to selected growers and in return to buy all the fresh fruit bunches harvested from their plots. Socapalm was also asked to bear the cost of maintaining the roads of the plantation and the cost of transportation of FFB from the farm to their mill. The growers on their part had to bear $5 \%$ of the cost of land and to pay back the entirety of their loan with an $8 \%$ interest for a period of 8 years. Mitfund is the institution created by Afriland First Bank to ensure that farmers effectively paid their loan. Mitfund is in charge of the monitoring and assessment on the progress of reimbursement of the loan by the growers; MC2 is a micro finance institution whose main responsibility was to pay the net income of the growers after all the deductions had been done.

To become a contractor, the following documents were required: registre de commerce (official registration), carte de contribuable (tax payer registration), patent rights and CNPS (National Social Insurance Fund) contribution for workers. Photocopies of these documents with an application form are deposited at the company. Candidates also need to hire skilled workers for field operations.

According to the agreement, the farmer was supposed to undertake the day to day management of his plot and this could be done through one of the following actors: the grower and his family; the hiring of a temporary or permanent work force or the cooperatives. In case of failure, Socapalm could step-in to manage the plot for the grower. In usual cases, Socapalm was there to provide the necessary technical expertise while in the case of full overtaking, Socapalm will oversee all operations on the plot, including the recruitment and payment of labour and the work scheduling and execution.

No particular criteria were used to partition plots to those who met all the requirements. As noted by most people, one of the greatest hindrance which prevented people to buy plots was the 5\% down-payment needed. Under such a policy, people who were not members of the villages with ancestral rights to the concession area but were rich enough to pay for these $5 \%$ were able to buy plots. Thus discrepancies in plot allocation occurred in many ways. The plots were not equally distributed as those who earned more were able to acquire more plots. It was also possible for members whose villages did not fall into the concession area to get plots. According to the Director of Socapalm Eseka, when the project started, priority was given to people from whom Socapalm was using their ancestral land. Although when Socapalm managers realized that some of these persons were not interested to join the project, they had to accept people of the same ethnic group (Bassa) but without any ancestral claims to the land.

\subsubsection{Discrepancies in plots allocation}

Several farmers claimed that the sensitization phase before the start of the project was not properly implemented. They argued that information about the implementation of the scheme was in the hands of a group of persons only, mostly the internal and external elites of the villages. More, information was not well circulated through the organization of village meetings gathering all stakeholders including Afriland First Bank, Socapalm, divisional officers of the area, local chiefs, internal and external elites and local populations of the villages who had customary rights to the land used by Socapalm. Farmers further stressed the fact that because of these failures there was a lot of discrepancies in the attribution of plots to the local population. It was stipulated in the original agreement that $25 \%$ of the plots had to go to the elites while $75 \%$ of the plots were 
Table 3. Yearly replanting program for the old palms.

\begin{tabular}{cccccccccc}
\hline \multicolumn{4}{c}{ Area already replanted } & \multicolumn{4}{c}{ Area expected to be replanted } & Total \\
Year & 2008 & 2009 & 2010 & 2011 & 2012 & 2013 & 2014 & 2015 & (ha) \\
\hline Areas (ha) & 300 & 300 & 300 & - & 300 & 601 & 400 & 400 & 2601 \\
\hline
\end{tabular}

Source: Field survey in SOCAPALM Eseka, 2013.

supposed to be the property of the local population (those who strictly rely on agriculture for their subsistence). In reality the exact contrary happened as internal and external elites grabbed the majority of the plots. Some plots were even attributed to persons whose villages did not have customary rights in the concession area, however still of Bassa'a extraction, except two non-natives from the Northwest region. Most of the elites who owned plots in the scheme were "absentee landlords" who can hardly locate their plots in the field.

Another group of people (locals/farmers) claimed that the sensitization phase of the project was well carried out and that detailed information on the implementation of the project was circulated, but that some local people were reluctant to be part of the project. Some of the reasons for such reluctance were:

- Villagers considered that they had customary rights to the land and thus did not see why the company would want to rent them a land that is actually their property.

- Others didn't see any interest in acquiring old palm stands which were no longer fully yielding. Indeed, most of the palms were already above 34 years of age, thus far above 25 years which is considered as the standard economic life of a plantation.

- The 5\% compulsory fee as the final criteria for eligibility to own a plot was also a major obstacle, which helped elites to grab more plots than poor farmers.

- It was even heard through the grapevine that after the payment of the $5 \%$ initial fee, the company might close down its activities in Eseka.

\subsubsection{Socapalm fully controls plot management}

When the project started in 2007, Socapalm was in charge by contract to provide technical assistance to the cooperative managing the plots for the growers. The cooperative was responsible to undertake the day-to-day management of the plots. This could be done through the recruitment of labour either through the use of temporary labour or the recruitment of contractors or through individual contracts on specified periods or through the attribution of specific operations to contractors who had the required skill and labour force. The cooperative was requested to have a management team headed by a President, a Secretary, with field staff to supervise contractors. The cooperative was also established to raise money through compulsory monthly payments from the planters. This sum was 2052 FCFA ( $3.13 €)$ /ha and spontaneous contributions from the planters depending on the need, the taking of credit from Socapalm and MC2 to be paid with minimal interest. The first cooperative to be part of the scheme was Socofepnyk, but it did not last long as power tussle inside the cooperative led to its splitting into two different entities and another cooperative named "Le Planteur" emerged. In June 2013, another cooperative named "SCAB (Société coopérative Agri-Business)" was created resulting from another split of "Le Planteur". When the management of the plots was in the hands of these cooperatives, the management staff did very little to follow up agricultural activities on the plots not to mention the embezzlement of funds originally dedicated to the plot management. This poor situation led Socapalm to take full control of the management of the plots as soon as the previous director of the project was sacked for the misappropriation of funds destined for the project in 2011. At present, Socapalm manages all the farming operations. The company recruits temporary and contracted workers and its staff schedules and assesses all field operations. All expenses incurred in the course of farm operations with exception of FFB transportation and road maintenance are billed to the planter who in turn is requested to supply FFB to Socapalm for repayment. Socapalm began to replace old palm stands in 2008 at farmers' expense as shown on Table 3.

Socapalm is paying back the loan contracted with Afriland First Bank on a monthly basis on behalf of the planters whose plots are unable to meet up with the credit re-imbursement. It is thus expected that by 2015, the loan of Afriland First Bank would have been fully paid.

That notwithstanding, the farmers will have to pay back this money to Socapalm through the production and supply of FFB from their plots. The size of a plot averages 8 to 10 ha and the amount of money to pay for a given plot depends on the distance to the mill and on the yield and height of the palms. As such the cost per plot ranges from $262000 \mathrm{FCFA} / \mathrm{ha}$ to $1006000 \mathrm{FCFA} / \mathrm{ha}(399.42$ to $1533.64 € / \mathrm{ha})$. Indeed, a farmer who owns a 10 ha plot with a 1006000 FCFA/ha rate is expected to pay: $(1006000 \mathrm{FCFA} \times 10 \mathrm{ha})+8 / 100 \times$ $(1006000$ FCFA $\times 10$ ha $)=10806480$ FCFA $(16474.4 €)$ including the payment of $8 \%$ interest.

It is from the main capital that Afriland First Bank had to pay $95 \%$ to Socapalm on behalf of the planters, with the planters themselves paying just $5 \%$. This means that in the present case, the farmer is supposed to reimburse the sum of $(95 / 100 \times 10006000+8 / 100 \times 10006000)$ FCFA $=10306180$ FCFA $(15711.69 €)$ and this credit is supposed to be repaid after 8 years. So 10306180 FCFA/8 years $=1288272.5 \mathrm{FCFA} /$ year (1963.96 €/year) is the amount of money the planter is supposed to reimburse per year.

In order to complete the reimbursement on a monthly basis, a schedule (Tab. 4) was designed which took into account changes in FFB yields during the year. The January to June period is the peak season, while the July-December one is considered as the low season for oil palm fruit production.

The order of monthly payments from the farmer is as follows: (1) the debt to Afriland First Bank for that month, (2) the cost of various farm operations for that month and 
Table 4. Monthly distribution in $\%$ of yearly sum for credit reimbursement.

\begin{tabular}{ccc}
\hline Month & $\begin{array}{c}\% \text { of } \\
\text { monthly } \\
\text { repayment }\end{array}$ & \% cumulated \\
\hline January & $10.0 \%$ & $10.0 \%$ \\
February & $14.0 \%$ & $24.0 \%$ \\
March & $19.0 \%$ & $43.0 \%$ \\
April & $17.0 \%$ & $60.0 \%$ \\
May & $13.0 \%$ & $73.0 \%$ \\
June & $7.0 \%$ & $80.0 \%$ \\
July & $4.0 \%$ & $84.0 \%$ \\
August & $2.0 \%$ & $86.0 \%$ \\
September & $2.0 \%$ & $88.0 \%$ \\
October & $3.0 \%$ & $91.0 \%$ \\
November & $4.0 \%$ & $95.0 \%$ \\
December & $5.0 \%$ & $100.0 \%$ \\
\hline
\end{tabular}

Source: SOCAPALM Eseka contract.

(3) payment of the cooperative management staff. The rest of income if any is kept in the farmer's account at MC2, the micro-finance institution acting for farmers. During interviews, farmers indicated that the cost of replanting that they used to pay in 2009 at $359238 \mathrm{FCFA} / \mathrm{ha}(547.66 € /$ ha) had increased to between 500000 FCFA and 550000 FCFA/ha ( 762.25 to $838.47 € /$ ha) in 2013 . Table 5 shows the costs distribution for the replanting of one hectare of old palm grove (November 2009). According to the Director of Socapalm Eseka, the cost of various farm operations has increased because at first not all the operations were performed: for example the old palms were not fertilized but today the replanted ones receive fertilisers, which increases the costs.

Our survey shows that more men than women own plots within the SOCAPALM Eseka scheme. Out of the 102 owners, female owners are just about 15: they work in the public or private sector, with an average age of 45 to 55 years.

When the project started, the maintenance of plots was in the hands of the planters through their cooperative, with some technical assistance from Socapalm. This situation did not last long as some of the farm operations were signed on paper but not executed in the field. The situation has then been 'rescued' by Socapalm which took over the full management of the plot, but then farmers are complaining about increasing costs. The result is that such plots are not yielding any benefit to the grower at present and farmers are claiming that they are presently working and losing money, since after all monthly payments have been deducted, there is nothing left. Another striking problem is labour, because most of the workforce comes from the Northwestern and Northern regions of Cameroon. The young natives from Eseka consider field work as too strenuous and they do not accept waiting for payout until the end of each month. Power struggle in cooperatives is leading to recurrent splitting and subsequent generation of new entities thus weakening the bargaining force with the company. Farmers also complain about the absence of a regulatory body in charge not only of establishing monthly prices for
FFB based on market trends for CPO but also of following up the contract signed between farmers and Socapalm and ensuring that their implementation is fairly balanced between both parties.

\subsubsection{A comparaison between FONADER and Afriland First Bank sponsored schemes}

- The FONADER sponsored scheme was established by the Government of Cameroon with the aim of fighting poverty with a focus on local populations living close to the agroindustries. Among the criteria for eligibility the candidate had to get $75 \%$ of income from farming activities; the farmer was requested to own land accredited by the village chief; he was to provide labour from his household and he was requested to be at least 25 years of age.

- Candidates who were eligible to join the FONADER scheme were not supposed to pay any entrance fee, contrary to the Afriland First Bank sponsored scheme, in which eligible candidates were supposed to pay $5 \%$ of the cost as an initial settlement. Also FONADER was using public funds, while Afriland First Bank is a private bank.

- The mechanisms of the two schemes are not so different. Indeed the money for the development of plantations for smallholders in the FONADER scheme was handed to the company in cash and the company was requested to develop the smallholder plot and provide the necessary inkind resources and technical services to the smallholder or landowner. The company made profit from the supply of Fresh Fruit Bunches from the smallholders' farms and it also determined the price of FFB. The farmers could repay their loan through the supply of FFB to the company. The slight difference in the two schemes is that in the case of Afriland Firstbank, both Socapalm and the German Development Bank provided a guarantee. In case the smallholders do not comply with the repayment of their credit in due time, the company would be forced to use this money to complete the loan on behalf of the farmers. This is a strong incentive for the company to push each farmer to pay back his loan.

Farmers involved in the scheme are quite optimistic about the future: after the company will have completed the replanting program in 2015, the oldest replanted palms will still yield during 17 years before the end of their economic life. During this period the yields will enable farmers to make enough profit. At present, the average yield for the old palms stands at 6 7 tons FFB/ha/year. Performance of newly replanted palms is expected to reach 15 to 20 tons $\mathrm{FFB} /$ ha at their most productive age (8 to 15 years) especially under good management practices. Farmers are still worried about theft of bunches from the young producing palms.

\subsection{Current measures adopted by agro-industries to strengthen links with smallholders}

Several agro-industries have tried to step up attractive prices for a kilogram of FFB as a way of directing more smallholders towards the company mill. As an example, CDC increased the price for a kilogram of FFB from 45 to 50 FCFA 
Table 5. Cost of replanting per hectare in 2009.

\begin{tabular}{cc}
\hline Different replanting operations & Cost in FCFA (Euros)/ hectare \\
\hline Felling of old palms & $90000(137.2 €)$ \\
Trimming and windrowing of fronds & $6500(9.91 €)$ \\
Lining & $4000(6.1 €)$ \\
Cutting and transportation of pegs & $2145(3.27 €)$ \\
Holing & $7150(10.9 €)$ \\
Loading of plants & $2860(4.36 €)$ \\
Off-loading and transportation of plants close to the hole & $3575(5.45 €)$ \\
Planting and application of fertilizer & $5720(8.72 €)$ \\
Phosphate tricalcium & $249(0.38 €)$ \\
Fully grown oil palm seedlings $\times 143$ & $224169(341.74 €)$ \\
Transportation cost & $12870(19.62 €)$ \\
Total & $359238(547.66 €)$ \\
\hline
\end{tabular}

Source: Field survey in SOCAPALM Eseka, 2013.

(0.07 to $0.08 €$ ) in 2011, while Pamol did the same in 2012 from 42 to 46 FCFA (0.06 to $0.07 €$ ) per kilogram FFB and the immediate payment in cash of at least $50 \%$ for a minimum quantity of FFB supplied to the company.

Currently Pamol buys a kilogram of FFB at 55 FCFA $(0.08 €)$ at mill gate and 51 FCFA $(0.078 €)$ farm gate. The price offered by Socapalm stands at 48 FCFA $(0.07 €) / \mathrm{kg}$ FFB. The cost to transport one ton of FFB from the farm to the mill is paid as follows: 4 FCFA $\left(6.1 \times 10^{-3} €\right)$ per $\mathrm{kg}$ FFB at Pamol; 2 to 3 FCFA $\left(3.1 \times 10^{-3}\right.$ to $\left.4.6 \times 10^{-3} €\right)$ at CDC and 5 FCFA $\left(7.6 \times 10^{-3} €\right)$ at Socapalm. Companies do not take into account the distance from the smallholder plantation to the company's mill, meanwhile independent transporters would ask smallholders to pay for transportation cost in accordance with the weight and the distance from the smallholder plantation to the industrial mill. Thus smallholders end up spending about 8000 to 12000 FCFA (12.2 to $18.29 €$ ) per ton FFB on transportation cost. However, such incentive measures decided by companies are not enough and their impact is hampered by several structural factors which include:

- the emergence of artisanal mills which pay instant cash and better prices to farmers (Nkongho et al., 2014);

- the poor status of road infrastructures/transportation logistics, which leads to high transportation cost for smallholders;

- the recurrent breakdowns in industrial mills due to wornout equipment and poor investment and maintenance;

- a low purchase price for FFB and the absence of any regulatory framework from the government that favors partnership.

\section{Discussion: The future of (partnerships in) the oil palm industry in Cameroon}

\subsection{Increasing investments from local elites}

Elites in Cameroon considered oil palm plantations not only as a way of securing an additional profit apart from their main source of income but also as a means of acquiring land that could be transferred to their heirs. It is also a way to boost their social status inside their community of origin (Levang and Nkongho, 2012; Ndjogui and Levang, 2013). This in turn helped in the stimulation of petty business in rural settings. It would thus be unfair to reduce the involvement of elites to land "grabbing". At a time when the State's involvement in the agricultural sector is almost insignificant, elites are virtually the only engine of agricultural development in Cameroon. Following the recurrent failure of major projects for agricultural development in the late 1980s, the implementation of the Structural Adjustment Programme in 1989 resulted in the withdrawal of the State from agricultural development and this has led to the collapsing of the agropastoral infrastructure in the country (Fonjong, 2004). This withdrawal was concomitant with a fall in prices of major agricultural export and it led to the virtual disappearance of sources of rural finance and consequently the contraction of economic activity. Hopes in the development of microfinance proved exaggerated, and traditional informal saving structures like the tontines remained the only financial instrument available to rural households. Unfortunately, the amounts of money redistributed by tontines are too small to support agricultural development projects and they are usually restricted to the support of social and cultural activities. As a result, the only efficient financial support in rural areas to date is provided by the elites. Of course this funding is dedicated to activities initiated and controlled by the elites themselves. But the supply of money for the purchase of land is redistributed to landowners of the village and the establishment of plantations generates significant employment opportunities for the poorest households. Unfortunately the money raised by the sale of land is seldom used to support any productive investment and employment opportunities are mainly captured by migrants. Should we then prohibit or discourage investment by elites? In this case, they are not responsible for the misuse of money from the sale of land by the villagers. Clearly, the problem that is facing the rural poor in Cameroon comes less from the elites than from the absence of alternative sources of funding for agricultural development. Elites merely fill a vacuum and most probably the situation of the rural population will be even more vulnerable without their investments.

The recent interest of large oil palm companies from Southeast Asia to the Congo Basin and particularly to Cameroon can be either a blessing or a curse for the nonindustrial plantation sector. If the Government allows such 
companies to settle under the agro-industrial classic model, small farmers, villagers and elites will be quickly marginalized because they will be unable to compete. On the contrary, if the Government authorizes the granting of land to big companies with the mandatory integration of a large number of smallholders along the lines of NES schemes then it will build on the potential of poverty reduction provided by the smart cultivation of oil palm (Levang and Nkongho, 2012).

\subsection{A revamped partnership between smallholders and agro-industries}

Previous studies showed that fair and balanced agreements between agro-industries and smallholders can be of mutual benefit when compared to the standard agro-industrial model. Such agreements provide a means of cheap and effective use of local people as labor for agribusiness capitalist. In fact, the village plantations are explicitly recognized as a way to outsource production. According to Konings (1986) the CDC village plantation is less efficient because producers bare almost all the production costs as they get inputs and agricultural services in the form of a loan that must be repaid with interest after harvest; and more, agribusiness escapes loads from a complete proletarianization (payment of family members or casual laborers employed by the planter, social security, housing, etc.). Smallholders schemes provide a less risky production system for agro-industries because the fluctuation of prices on the world market automatically affects producers who also bear the risk of crop failure.

According to Carrère (2010) and Nkongho et al. (2014), the benefits deriving from village plantations are numerous. Indeed they guarantee a stable income to planters, they promote security in land tenure and they enhance the monetization of the rural settings thus generating development. It is also argued that village plantations induce individualization of land and contractual liabilities (debts) that destabilize traditional institutions. Smallholder schemes are also suspected of further marginalizing the poorest social groups (youth and women) and finally they can deepen inequalities as elites stand out even more from the rest of the community (Carrère, 2010; Gerber, 2008).

According to Rival and Levang (2013), the choice of the model for oil palm development is not a technical one, but a societal choice. Egbe (2004) also stresses the need for rural women to be taken into consideration concerning funding opportunities for agricultural projects to alleviate poverty.

\subsection{New foreign investors: Herakles Farms as the first of a new kind of investors}

Due to increasing global demand for palm oil and suitable conditions for oil palm development, Cameroon has witnessed a sharp rise in investors' enquiries seeking land to plant oil palms since 2009. At least six companies are currently trying to secure over 1 million hectares of land for the production of palm oil in the southern forest zone. These companies include Sithe Global Sustainable Oils Cameroon
(SGSOC), Sime Darby, Biopalm, Goodhope, Palm Co and Smart Holdings, etc.

Sithe Global Sustainable Oils Cameroon (SGSOC) is a locally registered company in Cameroon, owned by Herakles Farms, (affiliate of Herakles Capital), based in New York USA. Herakles Farms acquired 100 percent ownership of SG Sustainable Oils from Sithe Global, an affiliate of the Blackstone Group, in 2009 (Hoyle and Levang, 2012).

At first, the total concession requested from government by SGSOC was 73086 ha (30600 ha in Ndian Division and 42600 ha in Kupe-Muanenguba Division). The site of this proposed plantation lies inside a globally recognized biodiversity hotspot between the protected areas of Korup National Park, Rumpi Hills Forest Reserve, Bakossi National Park and Banyang-Mbo Wildlife Sanctuary. These are all key habitats for primates, elephants, buffaloes and a multitude of rare, endemic and IUCN red-listed species of animals and plants.

In September 2009, SGSOC signed an agreement with the Government of Cameroon's Ministry of Economy, Planning and Regional Development (MINEPAT). In 2010, SGSOC started the Environmental and Social Impact Assessment for the project. In September 2011, MINEP issued SGSOC an Environmental Certificate. SGSOC and Herakles Farms were members of RSPO, the Roundtable for Sustainable Palm Oil (Hoyle and Levang, 2012). SGSOC had to face stiff resistance from both the local population and local and international conservation NGOs. The local population complained that the project did not sufficiently address their needs and accused the government/company of land expropriation, a situation which, if not addressed carefully, can put the future generation into jeopardy as very little land will be available for subsistence farming and other developmental projects. The company was also accused of lack of transparency in its dealings with some key ministries in the government. Local and international conservation NGOs claimed that the company did not sufficiently address issues related to the conservation of fauna and flora as its concession areas were surrounded by four protected areas of high conservation value forest (HCVF). The priorities of the company at first did not contain any will to develop the smallholder oil palm sector in its area of establishment. The company was accusing the local population of being manipulated by social and environmental NGOs for selfish motives, stressing the fact that the proposed area will greatly benefit from the much-awaited development needed by the local population through employment opportunities and social/infrastructural development.

After all the imbroglio between Herakles Farms, the local population and social and environmental NGOs, the Government of Cameroon finally decided by presidential decree (2013/416 of 25 November 2013) to grant Herakles Farms a provisional concession of 13195 ha in Nguti subdivision of Kupe Muanenguba Division. Decree No. 2013/418 of 25 November 2013 granted Herakles Farms another provisional concession of 5384 ha in Mundemba sub-division and decree No. 2013/417 of November 2013 granted another provisional concession of 1264 ha to Herakles Farms in Toko subdivision, both in Ndian division. Thus a total concession area of 19843 ha (from its previous demand of 73086 ha) was granted to Herakles Farms from the National forest domain. 
This means that $27.2 \%$ of the total concession requested by SGSOC was finally granted by the Government on a provisional basis. Apart from the concession leased by the Government to SGSOC to develop a nucleus estate, the company will also have to develop 10000 ha of land for farmers from the surrounding villages, with customary claims to SGSOC concession as a way to redress some of the socio-economic plights of the local population.

\subsection{Recommendations for oil palm development in Cameroon}

The development of the oil palm sector in Cameroon should embrace a broad perspective considering social, environmental and economic realities. If planned carefully, the development of oil palm can lead to strong economic development of the region, as well as a reduction in rural poverty. If not, the extension of palm oil plantations may result in the loss of high conservation value areas and in negative impacts on the livelihood of local communities and indigenous people (Hoyle and Levang, 2012; Skurtis et al., 2010).

In order to amplify the positive effects and reduce the negative impacts, there is a need for the government of Cameroon and involved stakeholders to develop a national palm oil strategy that can steer the rapid expansion of the sector and also ensure that expanded production does contribute to Cameroon's sustainable development goals. In order to achieve this goal, it is pivotal that the government urgently engages all stakeholders from the outset (including government departments, companies, local communities, international and local NGOs).

The development of oil palm in Cameroon needs to benefit from the experience of major producing countries by implementing such expansion according to the highest international standards (such as the ones established by IFC, the International Finance Corporation from the World Bank Group). A strategy for the smart development of the oil palm sector should consider the following directions:

- Invest in productivity and yield increase in the existing oil palm plantations using selected and certified planting material and adopting best management practices.

- Ensure that all future palm oil expansion in Cameroon is developed in a sustainable way with minimum impact on carbon emission levels and biodiversity, by focusing first on "degraded lands".

- Avoid the overall reduction of the primary forests with an emphasis on development of areas which are already deforested or cleared.

- All new oil palm development in Cameroon should adopt and implement the principles and criteria of the Roundtable for Sustainable Palm Oil (RSPO). The requirement to comply with the RSPO standards for palm oil production in Cameroon should be part of national policy and regulations.

- Make sure that smallholders benefit from the development of agro-industrial complexes, either by establishing outgrowers contracts following the current model in Southeast Asia (where a percentage of at least $30 \%$ of the total area is reserved for smallholders) or by establishing measures to support family farming (provision of selected seedlings, inputs, technical support, training, etc.).

- The rights and roles of indigenous people and local communities should be respected, notably the adoption of free, prior and informed consent (FPIC) policies and the transparent communication/publicity about any proposed plans to develop new plantations.

- Special attention should be paid to the reviewing of regulations related to land acquisitions in order to protect and secure local land rights (Feintrenie, 2013; Feintrenie and Rafflegeau, 2012; Hoyle and Levang, 2012; Sayer et al., 2013; Skurtis et al., 2010).

\section{Conclusion}

Before the independence and re-unification of the British and French Cameroon in 1961, very little was done to build partnership between agro-industries and oil palm smallholders. While agro-industries like Pamol and CDC benefitted from the utilization of quality tenera hybrid seeds and better milling efficiency, oil palm smallholders on the other hand harvested the native dura variety either from wild oil palm groves or planted in their farmland mostly in agroforestry based systems. Smallholders also used artisanal traditional milling methods with much lower extraction rates and unhygienic conditions to produce red palm oil.

After independence and re-unification, as a means to boost oil palm production and fight poverty, the Government of Cameroon established SOCAPALM under a Nucleus Estate Smallholder model and extended this model to CDC and Pamol under the FONADER development scheme. Although this project greatly improved livelihoods through the provision of technical assistance, quality planting material and inputs like fertilizers, herbicides and pesticides at subsidized rates, the project lasted only for 12 years, from 1978 to 1990 . The project also recorded numerous pitfalls and FONADER underwent bankruptcy.

Leaders used their positions in administration and managed to divert benefits that were meant for the poor. More, the project targeted only wealthy locals who owned land and did not provide any opportunities for the marginalized class like unemployed youths and women. Besides, contracts linking smallholders and agro-industries were unilaterally negotiated without the involvement of the local population.

The project also proved inefficient in the area of monitoring and evaluation by independent bodies. There was no strong incentive from companies to make sure that smallholders did repay their credit since the loan came from a completely different institution. Smallholders complained about the absence of transparency on the total amount to be reimbursed as well as on the modalities of reimbursement. After the collapse of the FONADER scheme and the implementation of the structural adjustment program, the Government did very little to develop the oil palm sector and to foster partnership between smallholders and agro-industries. The Projet Villagisation sponsored by Afriland First Bank, a pilot project of SOCAPALM Eseka with smallholders is not very different from the FONADER scheme, as it is marked with similar flares and shortcomings. 
As opposed to other cash crops like cocoa, coffee, and rubber that rely much on the international market, palm oil benefits from an increasing domestic and sub-regional market. The oil palm areas cultivated by agro-industries has remained relatively stable over the years while areas exploited by smallholders have tremendously increased over a short period, although recording very poor yields.

With the arrival of new oil palm plantation companies in Cameroon and the interest shown by already established companies to expand their cultivated areas, there will be significant changes (either positive or negative) in the oil palm landscape in the near future. The new companies - just like their older counterparts - will be requesting new areas to develop/expand their plantations. Public attention must be paid to the granting of these areas in order to avoid any additional forest conversion, habitat destruction for wild animals, social crises with indigenous and local populations and increased pollution to the environment. Also the domestic and sub-regional market that used to exist may drastically be saturated and as such there will be need for new markets not only for agro-industries but also for smallholders.

Our study proposes the development of a national strategy document for the oil palm industry that will serve as a road map for the new and old palm oil companies seeking for land to develop oil palm. Such a consensus document should focus on yield improvement, on the establishment of legal and institutional frameworks to acquire land from the Government, the inclusion of a national interpretation of RSPO Principles and Criteria to guarantee future markets and the securing of appropriate funds.

Last but not least, there is a clear need for a political will and the promotion of transparent and innovative measures by government in order to strengthen partnership between agroindustries and oil palm smallholders. The shortcomings of the FONADER and Afriland First Bank sponsored schemes call for future partnership schemes in the oil palm sector to be mutually beneficial and sustainable. All these measures will greatly help in avoiding the adverse effects of oil palm development and in meeting up with the poverty reduction strategy put in place by the government of Cameroon.

Acknowledgements. The authors are grateful to the CGIAR Research Program on Forests, Trees and Agroforestry (http://www.cifor.org/ forests-trees-agroforestry) for their support and to ANR (French National Research Agency) for their support through the Sustainable Palm Oil Project (SPOP) (http://spop.cirad.fr). We would also like to thank all donors who supported this research through their contributions to the CGIAR Fund (https://www.cgiarfund.org/FundDonors). Special thanks also goes to the anonymous reviewers for their useful comments.

\section{References}

Andela ST. 2006. Optimisation des Postes de travail et mise en œuvre des outils de la qualité. Site d'étude: Socapalm Mbongo. Diplôme d'étude supérieures approfondies, ESSEC, Université de Douala, $118 \mathrm{p}$.

Bakoumé C. 2006. Sustainable Development of Oil Palm in Africa: Smallholders' Sector. International Planters Conference, 7 p.
Bakoumé C, Jannot C, Rafflegeau S, Ndigui B, Weise S. 2002. Études complémentaire sur la relance des filières hévéa et palmier à huile. IRAD, CIRAD, IITA, FAO, 80 p.

Barbier JC, Courade G, Tissandier J. 1980. Complexe agro-industriels au Cameroon. Editions de L'office de la Recherche Scientifique et Technique Outre-Mer (ORSTOM), Paris, 281 p.

Berderman SH. 1968. Partner in National Growth, CDC, 80 p.

Cameroon Tribune 2013. Communes. Les réalités de la cohabitation, $32 \mathrm{p}$.

Carrère R. Cameroun. In: Le palmier à huile en Afrique. Le passé, le présent et le futur. Mouvement Mondial pour les Forêts Tropicales, 2010, pp. 23-27.

Cheyns E. and Rafflegeau S. 2005. Family agriculture and the sustainable development issue: possible approaches from the African oil palm sector. The example of Ivory Coast and Cameroon. OCL 12: 111-120.

Courade G. 1984. Des complexes qui coûtent cher. La priorité agro-industrielle dans l'agriculture camerounaise Agro-industrie, 1984: 75-91.

Egbe HA. 2004. An assessment of the role of financial credit for rural women in extending their palm nut farms: Case study of South West Cameroon. Submitted in partial fulfilment for the Master Degree in Women's Law, Southern and Eastern African Regional Centre for Women's Law, University of Zimbabwe, $31 \mathrm{p}$.

Elong JG. 2003. Les plantations villageoises de palmier à huile de la Socapalm dans le bas-Moungo (Cameroun) : un projet mal intégré aux préoccupations des paysans. Les Cahiers d'Outre-Mer 224: 11 p.

Feintrenie L. 2012. Transfer of the Asian model of oil palm development: from Indonesia to Cameroon. World Bank conference on land and poverty, April 23-25, Washington DC.

Feintrenie L. 2013. Oil palm business models. $4^{\mathrm{e}}$ conference international biocarburants et bioénergies. 2ie, CIRAD, Ministère des Mines et de I'Energie : Ouagadougou, Burkina Faso, 21-23 novembre 2013.

Feintrenie L, Rafflegeau S. 2012. Oil palm development: risks and opportunities based on lessons learnt from Cameroon and Indonesia. XVII International oil palm conference 2012, September 25-28, Cartagena Colombia.

Foko E. 1994. Les Paysans de L'Ouest Cameroon face au crédit agricole institutionnel. Economie Rurale 219: 12-15.

Fonjong LN. 2004. Changing fortunes of Government policies and its implications on the application of agricultural innovations in Cameroon. J. African Stud. 13: 13-29.

Gerber JF. 2008. Résistances contre deux géants industriels en forêt tropicale populations locales versus plantations commerciales d'hévéas et de palmiers à huile dans le Sud-Cameroun. Mouvement Mondial pour les Forêts Tropicales, 44 p.

Hirsch R. 2000. Dynamique récente des plantations individuelles de palmier à huile au Cameroun. OCL 7: 172-174.

Hirsch RD. 1995. Le Palmier à huile en Afrique: La nécessaire relance. Plantations Recherche Développement, 2: 19-30.

Hoyle D, Levang P. 2012. Oil palm Development in Cameroon. An ad hoc working paper prepared by WWF, IRD and CIFOR, $16 \mathrm{p}$.

Jannot C. 2010. Emplois, économie, environnement: Le développement de la filière palmier à huile en Côte-d'Ivoire. OCL 17: 393 399.

Jannot C. 2003. Oil palm in Africa. BUROTROP Bulletin 19: 15-18.

Kiple KF. 2000. The Cambridge World History of Food. 2 volume boxed set. Bowling Green State University, Ohio Kriemhild Coneè Ornelas.

Konings PJJ. 1986. L'Etat, l'agro-industrie et la paysannerie au Cameroun. Politique africaine (22) 120-137. Free online available at: http://hdl.handle.net/1887/3489. 
Konings PJJ. 1993. Contract farming and capital accumulation in Cameroon: the case of the CDC smallholder schemes, In: Geschiere PL, Konings PJJ, eds. Itinéraires d'accumulation au Cameroun $=$ Pathways to accumulation in Cameroon. Paris Karthala, pp. 217-239. Free online available at: http://hdl.handle. net/1887/4606.

Konings PJJ. 1996. Privatisation of agro-industrial parastatals and anglophone opposition in Cameroon. J. Commonwealth and Comparative Politics 34: 199-217. Free online available at: http://hdl.handle.net/1887/4614.

Konings PJJ. 1997. Agro-industry and regionalism in the South West Province of Cameroon during the national economic and political crisis. In: Nkwi PN, Nyamnjoh FB, eds. Regional balance and national integration in Cameroon: lessons learnt and the future. Yaoundé: ASC/ICASSRT, pp. 289-306. Free online available at: http://hdl.handle.net/1887/4615.

Lebailly P, Tentchou J. 2009. Étude sur la filière porteuse d'emploi "palmier à huile". Rapport final, OIT, Ministère de l'Emploi et de la Formation Professionnelle, Yaoundé, 96 p.

Levang P, Nkongho RN. 2012. Elites et accaparement des terres au Cameroun: L'exemple du palmier à huile. Enjeux 47-48: 67-74.

Ndigui B, Koona P, Kaho F, et al. 2006. Construction d'un appui technique aux planteurs de palmier à huile (Elaeis guineensis Jacq) des provinces du Littoral et du Sud au Cameroun. La Dibamba: IRAD, $21 \mathrm{p}$.

Ndjogui TE, Levang P. 2013. Elites Urbaines, élæiculture et question foncière au Cameroun. Nouvelles politiques foncières, nouveaux acteurs : des rapports fonciers sous tensions. Territoires d'Afrique 5: $14 \mathrm{p}$.

Ndjogui TE, Nkongho RN, Rafflegeau S, Feintrenie L, Levang P. 2014. Historique du secteur palmier à huile au Cameroun. Document occasionnel 109. Bogor, Indonésie: CIFOR.

Ndoum ANL. 2009. Analyse des contraintes et opportunités dans la production, la distribution et l'utilisation du matériel végétal sélectionné du palmier à huile: cas de la région du Littoral et du Sud au Cameroun. Mémoire présenté en vue de l'obtention du Diplôme d'Ingénieur Agronome, Option: Economie et Sociologie Rurales, Université de Dschang, 97 p.
Ngom E. Oil palm in Cameroon. Communication at the event 'Sharing what works in sustainable and equitable oil palm development'. Bogor, Indonesia, CIFOR, 21-27 September, 2011.

Nkongho RN, Feintrenie L, Levang P. 2014. Strengths and weaknesses of the smallholder oil palm sector in Cameroon. OCL 21: D208.

Nkongho RN, Feintrenie L, Levang P. 2014. The non-industrial palm oil sector in Cameroon. Working Paper 139. Bogor, Indonesia: CIFOR.

Nkongho RN, Nchanji Y, Tataw O, Levang P. 2014. Less oil but more money! Artisanal palm oil milling in Cameroon. African J. Agric. Res. 9: 1586-1596.

Oben RE, Fanso VG. 2012. The contribution of foreign aid to agroindustrial development in Cameroon. The case of CDC 19471997. Master thesis, University of Yaounde 1, $125 \mathrm{p}$.

PACA. 2009. Étude de faisabilité d'un programme de développement des plantations villageoises de palmier à huile dans le cadre du projet-PACA-, $155 \mathrm{p}$.

Rafflegeau S. 2008. Dynamique d'implantation et conduite technique des plantations villageoises de palmier à huile au Cameroun : Facteur limitant et raisons des pratiques. Thèse de Doctorat, AgroParisTech, CIRAD, IRAD, 148 p.

Rafflegeau S, Michel-Dounias I, Tailliez B, Ndigui B, Papy F. 2010. Unexpected $\mathrm{N}$ and $\mathrm{K}$ nutrition diagnosis in oil palm smallholdings using references of high-yielding industrial plantations. Agron. Sustain. Dev. 30: 777-787.

Rival A, Levang P. 2013. La palme des controverses. Palmier à huile et enjeux de développement. Paris: Editions Quae, IRD/CIRAD, $98 \mathrm{p}$.

Sayer J, Ghazoul J, Nelson P, Boedhihartono AK. 2013. Oil palm expansion transforms tropical landscapes and livelihoods. Global Food Security 1: 114-119.

Skurtis T, Aïnaché G, Simon D. 2010. Le financement du secteur de l'huile de palme: pourquoi les institutions financières de développement doivent continuer à investir en Afrique. $O C L$ 17: 400-403.

Cite this article as: Raymond N. Nkongho, Thomas E. Ndjogui, Patrice Levang. History of partnership between agro-industries and oil palm smallholders in Cameroon. OCL 2015, 22(3) A301. 